\title{
Indonesia dalam Pusaran Politik Energi Global
}

\author{
Angga Nurdin Rachmat \\ Universitas Jenderal Achmad Yani
}

\begin{abstract}
Energy emerges as a strategic issue as industrial countries begin to strive to increase their economic growth. This condition is related to the need for source, distribution and price of guaranteed energy sources. The achievement of these conditions will not be easy because the must compete each other for energy accsess. However, for developing countries with considerable energy reserves this condition leads them in two situations where the first will be a bargaining power that leads to the achievement of national interests and on the other hand will be a curse that makes them an object of exploitation of advanced industrial countries. Referring to these conditions Indonesia is a country with a lot of resources. Therefore, this paper describes the dynamics of global energy politics and how Indonesia should take advantage of the opportunity of the dynamics of global energy politics.
\end{abstract}

Keywords: global energy politics, industrial countries, Indonesia

\begin{abstract}
Abstrak
Energi telah muncul sebagai isu strategis bagi negara industri dalam rangka meningkatkan pertumbuhan ekonomi. Kondisi ini tentu saja membutuhkan jaminan ketersediaan, distribusi dan harga yang terjangkau dari sumber energi. Untuk mencapai kondisi tersebut tentu bukan hal yang mudah mengingat terjadinya kompetisi diantara sesama negara industri untuk mendapatkan akses sumber energi tersebut. Namun bagi negara berkembang dengan ketersediaan energi akan menajadi pisau bermata dua pada satu sisi akan menjadi instrumen dalam rangka meningkatkan posisi tawar dalam politik internasional dan disisi lain akan menjadi kutukan karena membuat mereka menjadi objek eksploitasi dari negara industri untuk memperoleh sumber energi. Merujuk pada hal ini Indonesia merupakan negara berkembang dengan cadangan sumber energi yang cukup besar perlu untuk mewaspadai pusaran politik energi global yang dimotori oleh negara-negara industri. Oleh karena itu artikel ini mendeskripsikan mengenai posisi Indonesia dalam pusaran politik energi global terkait dengan potensi cadangan energi yang dimilikinya.
\end{abstract}

Kata-kata kunci : politik energy global, negara industri, Indonesia 


\section{Pendahuluan}

Ketersediaan energi yang bersumber dari bahan bakar fosil (minyak dan gas) saat ini menjadi permasalahan strategis khususnya bagi negara-negara industri maju. Permasalahan muncul jika merujuk dalam penelitian Goldberg (1992: 15) yang memberikan proyeksi konsumsi energi dunia di masa depan dalam beberapa dekade terakhir sebelum tahun 1980 mencerminkan ekspektasi pertumbuhan yang berkelanjutan dari perkiraan 3 persen per tahun yang berarti konsumsi energi akan meningkat empat kali lipat dalam kurun waktu 50 tahun ke depan. Peningkatan konsumsi energi yang berhadapan dengan ketersediaan akan berbanding lurus dengan tingginya tingkat kompetisi dalam mendapatkan sumber energi tersebut khususnya diantara negara-negara industri maju. Tingginya tingkat kompetisi dalam memperebutkan sumber energi sangat rentan menimbulkan konflik. Konflik akan menjadi resiko mengingat energi merupakan factor krusial dari perkembangan teknologi dan pembangunan ekonomi (Chow, Kopp \& Portney, 2003).

Dalam kompetisi untuk mendapatkan sumber energi, aktor negara diposisikan sebagai konsumen dan produsen. Konsumen lebih banyak dari negara industri yang memerlukan komoditas tersebut sementara produsen kebanyakan merupakan pemilik dari komoditas energi. Interaksi yang kemudian terjalin tidak hanya kompetisi diantara negara industri namun juga bagaimana interaksi antara negara industri dengan negara produsen sumber energi. Hunter (1966) mengatakan bahwa salah satu negara yang memiliki cadangan sumber energi yang cukup besar adalah Indonesia sehingga menjadi mitra strategis bagi beberapa negara untuk memenuhi kebutuhan energinya.

Beranjak dari realitas tesebut maka dalam tulisan ini akan menyoroti mengenai posisi Indonesia saat ini dan apa yang harus dilakukan Indonesia dalam dinamika politik energi yang dijalankan oleh negara-negara industri maju. Pembahasan ini menjadi penting mengingat Indonesia memiliki cadangan sumber energi yang cukup besar yang berpotensi meningkatkan daya tawar Indonesia dalam politik energi global. Pembahasan dalam tulisan ini akan diawali dengan gambaran terkait ditempatkannya isu energi dalam kajian keamanan melalui proses sekuritisasi dalam ruang lingkup global. Sekuritisasi ini kemudian menyeret isu energi dalam pusaran politik yang dijalankan oleh negara-negara konsumen sumber energi. Implikasi dari kondisi ini adalah bagaimana posisi Indonesia sebagai sebuah negara dengan jumlah cadangan energi yang cukup besar dalam politik energi global. Terakhir, artikel ini menyoroti keberadaan cadangan energi Indonesia di masa depan sehingga menjadi bahan kajian terhadap kelangsungan pembangunan dan posisi Indonesia dalam politik energi global. 


\section{Sekuritisasi Energi dalam Politik Global}

Perluasan konsepsi keamanan telah membawa isu baru seperti permasalahan energi ke dalam ranah strategis bagi aktor-aktor yang terkait di dalamnya. Menurut Yani dkk (2017: 59) hal tersebut membuktikan bahwa keamanan tidak lagi bersifat obyektif melainkan inter-subyektif yang dikenal dengan sekuritisasi. Artinya, isu energi telah disekuritisasi oleh negara-negara industri maju mengingat kebutuhan yang semakin besar terhadap cadangan sumber energi yang semakin hari semakin berkurang. Meskipun hal ini telah disadari oleh Amerika Serikat sejak tahun 1914 pada saat Perang Dunia I, kesadaran akan peran vital dari ketersediaan energi semakin meningkat terkait dengan krisis minyak tahun 1973 karena embargo minyak dari Timur Tengah ke Amerika Serikat, Jepang dan negara industri di Eropa Barat. Para elit di Amerika Serikat dan Inggris menegaskan minyak sebagai public service, komoditi pasar dan salah satu penentu keamanan nasional (Ja`far, 2009: 100).

Negara-negara produsen minyak yang tergabung dalam Organization of Petroleum Importing Countries (OPEC) dan negara industri maju merupakan aktor utama dalam sekuritisasi isu energi. OPEC dan negara industri maju menyadari bahwa energi merupakan unsur yang sangat vital bagi perkembangan teknologi di samping secara politis memiliki konsekuensi bagi pertumbuhan ekonomi baik dalam tataran lokal, nasional, dan global; dan bahkan sistem politik internasional dapat mempengaruhi terbentuknya aliansi dan komitmen pertahanan nasional (Chow, Kopp \& Portney, 2003). Di sisi lain, terjadi kenaikan permintaan terhadap sumber energi yang semakin tinggi dari waktu ke waktu seiring dengan pertumbuhan ekonomi di negara-negara maju.

\section{Grafik 1}

Proyeksi Konsumsi Energi Dunia 2020-2040

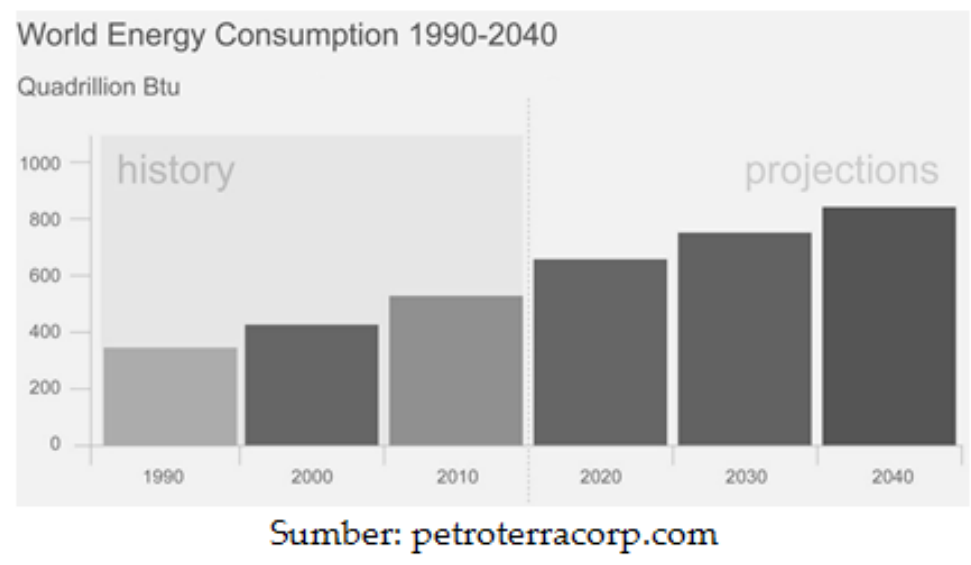


Berdasarkan realitas tersebut sekuritisasi terhadap isu energi tersebut memunculkan konsep energy security atau keamanan energi. Burgess (dalam Synder, 2008: 70) mengatakan bahwa saat ini energi telah menjadi dimensi sentral dalam merumuskan kebijakan keamanan. Setiap terjadi gejolak harga minyak dunia, misalnya terkait dengan instabilitas kawasan seperti konflik maupun gangguan jalur distribusi senantiasa menjadi perhatian dari negara-negara konsumen industri maju. Mereka melakukan perhitungan strategis untuk mengamankan pasokan minyak sekalipun dengan penggunaan kekuatan militer. Oleh sebab itu, energi serta ketersediaan maupun aksesnya menjadi obyek vital untuk diamankan dengan menggunakan berbagai sumberdaya yang dimiliki negara-negara.

Secara konseptual, Deese (1980) mendefiniskan keamanan energi sebagai kondisi dimana suatu negara merasakan probabilitas tinggi bahwa ia akan memiliki pasokan energi yang memadai baik energi yang bersifat tradisional maupun non-tradisional dengan harga terjangkau. Deese menekankan bahwa kondisi aman dalam isu energi ini adalah saat ada jaminan terhadap sumber energi, jalur distribusi dan stabilitas harga. Keamanan energi kemudian tidak hanya menjadi isu domestic setiap negara melainkan telah muncul sebagai permasalahan global. Dunia telah terintegrasi dan saling terkait satu sama lain tak terkecuali dalam hal ini adalah pasar energi global.

Burgess (dalam Synder, 2008: 70) menyatakan bahwa hubungan antara aktivitas pasar global dengan ancaman yang akan dihadapi dalam menjamin keamanan energi terkait dengan tiga hal yaitu krisis minyak, perubahan iklim dan stabilitas kawasan Timur Tengah sebagai penyedia sumber energi terbesar. Dengan demikian maka keamanan energi dan analisis keamanan energi saat ini menjadi elemen dalam menentukan politik luar negeri dan politik internasional. Hal ini tidak dapat dilepaskan dari kepentingan nasional suatu negara khususnya terkait dengan kebutuhan energi tersebut dalam pengambilan kebijakan luar negerinya terhadap negara lain (Deese, 1980).

Isu terorisme dan stabilitas di negara penyuplai menjadi pertimbangan penting dalam upaya untuk mencapai keamanan energi bagi negara-negara industri maju. Meskipun terorisme tidak lagi menjadi ancaman langsung terhadap wilayah maupun warga Barat, tetapi sabotase terhadap kepentingan-kepentingan Barat misalnya jalur distribusi energi masih cukup mengkhawatirkan. Hal ini terkait dengan penyebaran ideologi jihad global dan kenaikan harga minyak yang ikut mendorong aksi-aksi teror terhadap fasilitas energi negara-negara Barat di kawasan Timur Tengah yang mayoritas penduduknya Muslim (Koknar, 2009: 18). Saat ini yang menjadi perhatian adalah ancaman terorisme dan perompakan di wilayah perairan. Distribusi energi dalam jumlah besar seringkali dilakukan dengan meng- 
gunakan sarana transportasi laut. Oleh karena itu gangguan yang dihadapi oleh kapal-kapal yang memuat minyak, batu bara dan gas akan menganggu suplai energi tersebut sehingga perlu untuk diperhatikan.

Stabilitas di negara penyuplai energi sangat penting bagi negara konsumen. Negara penyuplai akan menjadi ancaman jika negara tersebut mengalami pergantian pemerintahan dengan rezim yang tidak kooperatif dan kemudian menghentikan pasokan energinya dan mengalihkannya kepada pihak lain. Hal ini pernah terjadi pada saat krisis minyak tahun 1960 dan 1970-an dimana negara-negara Timur Tengah menghentikan pasokan minyak terhadap Eropa dan Amerika Serikat. Hal ini kemudian menyebabkan naiknya harga minyak dunia yang membuat terganggunya stabilitas ekonomi global. Oleh karena itu, negara-negara Barat cenderung akan mendukung rezim yang kooperatif dengan negaranya untuk menjamin pasokan energinya tetap terjaga. Hal ini yang ditunjukan oleh Amerika Serikat terhadap negara-negara yang ada di Timur Tengah dengan senantiasa mendukung rezim yang berkuasa meskipun mereka tidak menerapkan standar-standar HAM maupun demokrasi yang sering dipromosikan kepada negara-negara lain.

\section{Politik Energi Global}

Berkembangnya industrialisasi membuat permintaan energi semakin bertambah. Kondisi ini yang kemudian membuat politik energi menjadi semakin kompleks. Terlebih bagi negara-negara industri baru baru seperti China dan India yang kemudian menyaingi Amerika Serikat dan Eropa sebagai konsumen energi terbesar. Akses energi sangat penting untuk mempertahankan pertumbuhan ekonomi di China dan India dimana industrialisasi yang dilakukan telah mempekerjakan ratusan juta orang sementara mereka masih berada dalam kemiskinan dan populasi yang terus tumbuh (Pasqual et al., 2010: 9). Bagi negara-negara tersebut industri mereka tidak boleh berhenti karena hal ini akan membuat terhambatnya pertumbuhan ekonomi yang menyebabkan kemiskinan dan pengangguran yang lebih besar. Karena itu, suplai energi yang menyokong industri tersebut harus selalu tersedia dan senantiasa ditingkatkan. Kondisi ini kemudian membuat negara-negara industri saling berlomba untuk mencari sumber energi di tempat-tempat baru. Konsekuensinya, perebutan sumber energi akan menjadi medan perang yang dahsyat di abad-21, meskipun di sisi lain juga mendorong kerjasama (Carton, 2009: 30). Hal ini membuat kekuatankekuatan besar dunia berada dalam kompetisi untuk menguasai cadangan energi yang ada di negara lain.

Fenomena kompetisi tersebut merupakan cermin dari upaya pencapaian kepentingan nasional untuk mendapatkan atau meningkatkan kekuasaan. Di masa yang akan datang besar atau kecilnya kekuasaan 
sebuah negara akan sangat ditentukan dari jumlah cadangan energi yang dimilikinya. Tanpa kita sadari fenomena perlombaan penguasaan energi yang dilakukan oleh negara-negara maju sebenarnya dimaksudkan untuk menghindarkan mereka dari penggunaan cadangan energi mereka sendiri. Sumber energi yang berasal dari luar akan digunakan untuk menopang industrialiasai dan sebagian akan disimpan sebagai cadangan. Mereka menyadari bahwa di masa depan cadangan tersebut akan sangat berharga untuk kemudian dijadikan sebagai sumber kekuasaan. Sebagai ilustrasi, meskipun sebuah negara memiliki ratusan atau bahkan ribuan kendaraan tempur canggih, tanpa adanya bahan bakar untuk menggerakannya maka kendaraan tempur yang bagaimanapun canggih dan hebatnya hanya akan menjadi pajangan semata. Oleh karena itu sumber energi juga menjadi indikator bagi kapabilitas sebuah negara dalam menjalankan perang dan mampu bertahan dalam kondisi yang tidak menentu.

Kompetisi dalam menguasai sumber energi membuat negara yang memiliki sumber energi menjadi korban. Fenomena ini dapat dilihat dari salah satu contoh kasus perang di Libya, dimana keputusan Khadafi untuk memberikan porsi lebih kepada perusahaan asal China membuat negara-negara Eropa merasa terancam, oleh karena itu serangan ke Libya juga memiliki motif untuk menyingkirkan perusahaan minyak China dari Libya. China memandang bahwa National Oil Company (NOC) adalah senjata bagi pemerintah China yang secara agresif melakukan eksplorasi dan produksi minyak diseluruh dunia untuk menjamin keamanan energi agar tidak disaingi oleh kompetitor energi yang lain (Downs dalam Pasqual \& Zambetakis, 2009: 73).

Hal yang sama juga terjadi dengan Irak dimana intervensi Amerika Serikat tidak dapat dilepaskan dari upaya penguasaan sumber-sumber minyak di negara tersebut. Hal ini terkait dengan pembagian konsesi eksplorasi minyak kepada perusahaan-perusahaan asal Amerika Serikat dan negara-negara sekutunya. Penguasaan terhadap sumber minyak di Irak tersebut sangat penting mengingat permintaan minyak sebagai sumber energi untuk menunjang industrialisasi mereka sangat besar. Jika Saddam Hussein tidak segera disingkirkan maka sumber minyak tersebut akan jatuh ke pihak lain yang sama-sama haus akan sumber energi di kawasan ini. Rutledge (2005: xi-xii ) mengungkapkan bahwa bukti sejarah menunjukan bahwa perhatian dan keterlibatan Amerika Serikat dalam permasalahan geopolitik minyak dengan sendirinya akan memberikan gambaran yang jelas mengenai alasan bahwa minyak adalah faktor kunci Amerika Serikat dan sekutunya untuk melakukan invasi ke Irak.

Kebutuhan akan energi ini membuat kebijakan strategis dari setiap negara industri menjadi dinamika yang menarik. Strategi ini bisa dilakukan dengan politik patronase yaitu mendikte negara sumber energi melalui berbagai bantuan ekonomi, militer maupun politik, liberalisasi pasar yang 
akan membuka pintu investasi dalam bidang minyak dan gas. Alternatifnya, negara industri bisa melakukan penggulingan pemerintahan yang tidak kooperatif seperti yang dilakukan Amerika Serikat di Irak. Pendekatan berbeda dijalankan oleh China dengan pragmatisme dalam pemenuhan kebutuhan energi mereka. China mulai melirik Afrika sebagai wilayah sumber pemenuhan kebutuhan energi setelah sulit untuk bersaing dengan Amerika Serikat dan negara Eropa lain di Timur Tengah dengan pendekatan yang sangat berbeda. China datang dengan berbagai bantuan serta investasi tanpa memberikan persyaratan yang biasa diberikan oleh Amerika Serikat dan negara Eropa lain. Kondisi ini tentu disambut dengan baik oleh negara-negara Afrika yang tengah membutuhkan investasi maupun bantuan ekonomi.

Bagi negara yang memiliki cadangan sumber energi yang besar, keberadaan sumberdaya tersebut merupakan anugerah sekaligus kutukan. Bagi negara yang mampu untuk mengelola dinamika persaingan antar negara maju dalam memperoleh akses terhadap sumber energi akan mampu memaksimalkan keuntungan demi kesejahteraan masyarakat maupun posisi dalam politik internasional. Namun, bagi negara yang kurang bijak dalam mengelola dinamika persaingan tersebut, maka kerugian besar akan menanti karena hanya menjadi obyek eksploitasi dari negara-negara yang berkepentingan. Eksploitasi ini seringkali tidak hanya dalam hal sumberdaya energi namun juga politik mengingat negara-negara industri akan melakukan berbagai strategi dalam rangka mengamankan akses terhadap sumber energi yang dimiliki oleh sebuah negara.

\section{Posisi Indonesia dalam Pusaran Politik Energi Global}

Indonesia dianugrahi kekayaan sumberdaya alam yang sangat melimpah, khususnya minyak bumi, gas alam dan batubara. Indonesia memiliki potensi yang sangat besar dalam energi; cadangan minyak sebesar 9 miliar barel dengan kapasitas produksi 500 juta barel per tahun, cadangan gas 182 triliun kaki kubik dengan kapasitas produksi 3 triliun kaki kubik per tahun, dan cadangan batubara 19,3 miliar ton dengan kapasitas produksi 130 juta ton per tahun (Prasetyono, 2008: 215-216). Oleh sebab itu, Indonesia sangat diperhitungkan negara-negara industri maju sebagai salah satu sumber cadangan energi untuk memenuhi kebutuhan energi mereka. Dengan kepemilikan sumber energi yang cukup besar Indonesia memiliki peluang yang cukup besar untuk memainkan peran dalam politik energi global yang saat ini menjadi perhatian dari negara-negara industri maju.

Cadangan sumber energi yang dimiliki membuat Indonesia pernah menjadi anggota OPEC; organisasi negara-negara pengekspor minyak. Keberadaan Indonesia dalam OPEC dapat dipahami sebagai salah satu mekanisme untuk menunjukan kapasitas dalam rangka menjaga stabilitas harga minyak dunia. Melalui OPEC, Indonesia telah menjadi bagian dari 
negara-negara dengan kepemilikan cadangan energi khususnya minyak bumi dengan orientasi ekspor. Keberadaan Indonesia dalam OPEC telah menunjukan kapabilitas dan kapasitas sumber energi yang dimiliki untuk berkontribusi terhadap pengaturan stabilitas harga minyak dunia. Di satu sisi, OPEC menjadi wadah bagi Indonesia untuk menunjukan peran dalam politik energi dunia. Di sisi lain, OPEC membawa dampak negatif bagi Indonesia terkait dengan upaya untuk menjamin kedaulatan serta stabilitas energi domestik karena belum siapnya Indonesia dalam mengelola sumber energi secara mandiri.

Tahun 2008, Indonesia memutuskan mengakhiri keanggotaannya di OPEC. Mawikere (2016) mengatakan terdapat dua faktor yang membuat Indonesia memutuskan keluar dari OPEC yakni ketidakmampuan Indonesia dalam memenuhi tuntutan kuota produksi minyak dan kebijakan stabilisasi harga minyak domestik yang terkait dengan harga minyak dunia. Dua faktor tersebut membuktikan bahwa meskipun Indonesia memiliki cadangan sumber energi yang cukup besar namun belum mampu memanfaatkannya sebagai instrumen untuk memainkan peranan dalam politik energi global. Cadangan sumber energi yang dimiliki Indonesia semestinya mampu menciptakan daya tawar saat berhadapan dengan negara-negara industri.

Selain dimanfaatkan untuk menopang daya tawar internasional, Indonesia juga dapat menggunakan sumberdaya alam untuk kesejahteraan rakyat. Kemakmuran dan keamanan negara, perusahaan, bahkan individu semua bermuara pada ketersediaan dari energi (Canton, 2009: 31). Ketersediaan energi akan menunjang pembangunan serta penciptaan lapangan kerja lewat industrialisasi yang secara langsung dapat dinikmati oleh rakyat. Kenaikan harga minyak dunia yang membuat kepanikan negara-negara lain, seharusnya menjadi peluang bagi Indonesia untuk mendapatkan keuntungan yang lebih dari hasil penjualan sumber energi khususnya minyak bumi tersebut sebagai modal pembangunan. Negara-negara yang memiliki cadangan minyak besar seperti Arab Saudi maupun Venezuela mampu memberikan jaminan terhadap ketersediaan sumber energi bagi kebutuhan domestik dengan harga yang terjangkau. Ketersediaan serta keterjangkauan harga bahan bakar maupun gas mampu menopang pertumbuhan ekonomi masyarakat yang pada gilirannya akan berkontribusi terhadap pembangunan nasional.

Menyadari posisi strategis energi dalam menopang pembangunan maupun keamanan negara, saat ini kebijakan energi nasional Indonesia diarahkan untuk mewujudkan ketahanan energi nasional. ${ }^{1}$ Ketahanan en-

${ }^{1}$ Ketahanan Energi merupakan istilah yang digunakan oleh Pemerintah Indonesia dalam Undang-Undang No.30 Tahun 2007 Tentang Energi. Pada pasal 2 dijelaskan bahwa ketahanan energi didasarkan kepada "energi dikelola berdasarkan asas kemanfaatan, rasionalitas, efisiensi, berkeadilan, peningkatan nilai tambah, keberlanjutan, kesejahteraan masyarakat, pelestarian fungsi lingkungan hidup, ketahanan nasional dan keterpaduan dengan mengutamakan kemampuan nasional". 
ergi mempunyai dua aspek yaitu keamanan energi dan kemandirian energi. Keamanan energi merupakan jaminan terhadap kebutuhan energi nasional jangka panjang sedangkan kemandirian energi merupakan kemampuan untuk menggunakan sumberdaya dan teknologi untuk memenuhi kebutuhan energi nasional (Kementerian ESDM, 2010: 179). Dalam hal keamanan energi, Indonesia sudah seharusnya mengedepankan upaya dalam memaksimalkan berbagai potensi sumber energi yang dimilikinya. Karena tidak seperti negara-negara lain yang saling berlomba untuk menguasai sumber energi di wilayah atau negara lain, Indonesia hanya tinggal memikirkan bagaimana mengelola dan memanfaatkan seoptimal mungkin sumber-sumber energi yang dimilikinya.

Namun hal ini tampaknya masih jauh dari kenyataan karena hingga saat ini sumber-sumber energi yang dimiliki oleh Indonesia masih diperuntukan untuk memuaskan kebutuhan energi dari negara lain. Hingga saat ini di sektor migas, penguasaan cadangan migas oleh perusahaan asing masih dominan. Data Kementerian ESDM menunjukkan 69,9 persen industri migas Indonesia didominasi asing, sekitar 70 persen di antaranya perusahaan asal AS seperti Chevron, Conoco Philips dan Exxon Mobil. Perusahaan migas nasional hanya menduduki porsi sebesar 29,1 persen dalam industri migas (Gandhi, 2014: 88). Hal ini menunjukan bahwa Indonesia seakan tidak memiliki kedaulatan dalam mengelola sumber-sumber energinya.

Seiring dengan semakin meningkatnya permintaan terhadap sumber energi fosil, Indonesia sebagai salah satu negara dengan cadangan energi yang cukup besar senantiasa menjadi incaran bagi negara-negara industri untuk memenuhi kebutuhan sumber energinya. Kondisi ini menjadi peluang sekaligus ancaman terkait dengan politik energi yang akan dijalankan oleh beberapa negara untuk menjamin kebutuhan energi mereka. Menjadi peluang jika pemerintah Indonesia mampu menjadikan cadangan energi yang dimiliki sebagai daya tawar dalam rangka memenuhi kepentingan nasional, khususnya untuk memenuhi kesejahteraan dan kemajuan rakyat. Dalam hal ini Indonesia harus memainkan peranan sentral untuk mengakomodasi semua pihak tanpa mengorbankan cadangan energi yang dimilki. Sementara akan menjadi ancaman jika Indonesia tidak mampu memainkan peranan tersebut karena akan menimbulkan persaingan tidak sehat diantara negara-negara yang berkepentingan dengan cadangan energi yang dimiliki Indonesia. Persaingan ini bukan tidak mungkin akan memunculkan instabilitas politik di dalam negeri bahkan upaya penggulingan pemerintahan seperti yang dilakukan di Libya maupun Irak dengan tujuan menguasai sekaligus menutup akses dari negara lain terhadap cadangan energi yang dimiliki oleh Libya dan Irak.

Oleh sebab itu, keamanan energi bagi Indonesia sama artinya dengan kedaulatan energi. Ironisnya, ketika saat ini Indonesia menjadi negara pengimpor minyak dan gas untuk memenuhi kebutuhan energinya. Batu- 
bara, gas alam dan sumber energi lainnya belum sepenuhnya digunakan untuk memenuhi tuntutan kebutuhan energi (Prasetyono, 2008: 216). Padahal dengan cadangan energi yang sangat besar Indonesia seharusnya dapat memenuhi kebutuhan energi dalam negeri tanpa harus mengandalkan impor minyak dari negara lain. Kedaulatan energi akan memungkinkan alokasi anggaran untuk impor energi tersebut dapat dialokasikan untuk kepentingan pembangunan dan kesejahteraan rakyat.

Permasalahan klasik yang sering dikemukakan hingga saat ini adalah ketersediaan sumberdaya manusia untuk mengelola sumber-sumber energi yang sangat berlimpah tersebut. Kondisi tersebut membuat Indonesia memiliki ketergantungan terhadap keberadaan investasi asing dalam bidang energi. Dengan demikian, masyarakat Indonesia tidak akan mampu menikmati sumber energi yang berasal dari wilayahnya secara langsung dan harus membayar dengan harga yang lebih mahal.

Ketergantungan kepada pihak asing dalam menyediakan dan memenuhi kebutuhan energi domestik menjadi permasalahan yang sangat serius untuk diselesaikan. Hampir seluruh aktivitas ekonomi maupun pertahanan negara masih menggunakan sumber energi dari bahan bakar fosil yang belum bisa dipenuhi secara mandiri. Kelangsungan hidup sebuah negara dari ancaman pihak eksternal akan terkait dengan kepemilikan cadangan energi untuk menggerakan seluruh Alat Utama Sistem Persenjataan yang dimiliki mengingat teknologi persenjataan masih dioperasionalisasikan dengan sumber energi yang berasal dari bahan bakar fosil.

Kondisi tersebut membuat Indonesia harus segera melakukan pembenahan terkait dengan tata kelola minyak dan gas sebagai sumber energi utama dalam menunjang pembangunan dan keamanan wilayah. Karena seperti yang dipaparkan sebelumnya, keberadaan dari cadangan energi Indonesia telah banyak menarik minat dari berbagai negara yang tengah berlomba-lomba dalam mendapatkan sumber energi khususnya energi fosil. Bila pembenahan tidak segera dilakukan, bukan tidak mungkin Indonesia hanya sebagai obyek dalam politik energi global yang memunculkan ancaman tidak hanya terhadap cadangan sumber energi namun lebih dari itu pada kemandirian bangsa Indonesia di berbagai sektor.

\section{Masa Depan Sumber Energi Indonesia}

Bila Indonesia tidak memiliki kedaulatan terhadap akses sumber energinya, maka dapat dipastikan cadangan energi yang dimiliki oleh Indonesia hanya akan menjadi pemuas kebutuhan energi negara-negara lain. Bukan tidak mungkin di masa yang akan datang rakyat Indonesia tidak dapat lagi menikmati sumber-sumber energi tersebut karena telah diangkut oleh negara-negara lain. Kondisi ini tentu saja membahayakan bagi kelangsungan hidup bangsa Indonesia. Hal tersebut berarti Indonesia akan 
sangat tergantung kepada pihak lain yang kemungkinan akan memonopoli distribusi sumber energi yang sangat terbatas.

Tidak seperti negara-negara maju, kebijakan energi Indonesia masih mengandalkan eksplorasi, belum melakukan upaya-upaya untuk menyimpan cadangan tersebut untuk kebutuhan di masa depan. Menurut Prasetyono (2008: 217) tujuan utama kebijakan energi Indonesia sebagai negara berkembang adalah kontribusi energi terhadap pembangunan nasional dengan menyediakan sumber energi yang bersih dan murah bagi rakyat. Impor energi yang dilakukan Indonesia masih digunakan untuk memenuhi kebutuhan konsumsi energi bukan dalam rangka untuk menambah cadangan energi. Terlebih saat ini kemampuan produksi lapangan minyak bumi semakin menurun sehingga membatasi tingkat produksinya. Dalam satu dekade terakhir, kapasitas produksi kilang Bahan Bakar Minyak (BBM) dalam negeri tidak bertambah, sedangkan permintaan BBM di dalam negeri meningkat dengan cepat. Sebagai contoh pada 2005 impor minyak bumi untuk kebutuhan bahan baku kilang BBM sudah mencapai 40 persen sedangkan impor BBM untuk pemakaian dalam negeri mencapai 32 persen (Kementrian Riset dan Teknologi, 2006: 3). Data tersebut memperlihatkan bahwa hingga saat ini Indonesia masih belum mampu untuk memenuhi keamanan maupun kemandirian dalam hal energi. Terlebih dengan pasokan yang masih banyak tergantung kepada negara lain padahal di negara sendiri cadangan energi melimpah semakin membuat Indonesia berada dalam posisi yang sangat rawan dalam menyediakan kebutuhan energi bagi rakyatnya di masa yang akan datang. Meskipun saat ini telah banyak dilakukan riset dalam mencari energi alternatif, tetapi hal tersebut membutuhkan waktu yang sangat panjang dalam implementasinya.

Kondisi itu masih diperparah dengan usia industri minyak bumi nasional yang masuk kategori tua; lebih dari 100 tahun sementara produksinya semakin menurun. Sepanjang sejarah Indonesia, puncak produksi minyak terjadi sebanyak dua kali yaitu pada 1977 dan 1995 dimana produksi minyak bumi masing-masing sebesar 1,68 juta dan 1,62 juta barel per hari. Setelah 1995 produksi minyak Indonesia rata-rata menurun sekitar 12\% per tahun (Hutagalung et al., 2015: 2). Di samping penurunan produksi, permasalahan lain yang harus diperhatikan adalah berkurangnya cadangan energi yang ada di Indonesia. Menurut Kementerian ESDM tahun 2009 cadangan minyak mentah Indonesia akan habis dalam kurun waktu 22.99 tahun, gas selama 58.95 tahun dan batubara selama 82.01 tahun. Hasil perhitungan ini menggunakan asumsi bahwa tidak ditemukan lagi ladang-ladang baru sebagai sumber energi fosil. Sementara, konsumsi menunjukkan bahwa konsumsi energi Indonesia mengalami peningkatan dari tahun ke tahun. Pada periode 2000-2008, konsumsi energi akhir mengalami peningkatan rata-rata per tahun sebesar 2.73 persen dari 764.40 juta menjadi 945.52 
juta barel (Elinur et al., 2010: 98).

Apabila pemerintah Indonesia tidak secara serius memperhatikan masalah keamanan dan kemandirian energi saat ini bukan tidak mungkin di masa yang akan datang Indonesia hanya akan jadi penonton saat negara-negara masih dapat menggunakan sumber energi bagi kebutuhan rakyatnya. Hal ini dapat terjadi karena Indonesia mungkin telah kehabisan cadangan energi yang telah banyak dieksploitasi oleh negara-negara lain, sementara kelangkaan energi akan membuat negara lain enggan untuk menjual cadangan energinya kepada Indonesia. Selain itu, walaupun ada yang akan menjual sumber energi dapat dipastikan akan dibanderol dengan harga yang sangat mahal. Hal ini akan membuat Indonesia akan semakin sulit untuk berkembang dikarenakan stagnasi industri dan pembangunan akibat kelangkaan sumber energi tersebut. Terlebih jika ketergantungan kepada energi fosil belum dapat sepenuhnya dilepaskan maka dapat dipastikan alokasi dana untuk pemenuhan sumber energi tersebut akan semakin membengkak dan membebani anggaran negara sehingga memotong anggaran untuk alokasi kesejahteraan maupun pendidikan.

Berdasarkan realitas tersebut energi yang akan menjadi barang yang sangat langka di masa yang akan datang. Oleh karena itu, pemerintah harus bijaksana dalam menggunakannya serta berupaya untuk memelihara cadangan-cadangan energi yang dimiliki. Sinergi antara kebijakan pemerintah dalam bidang energi dan kesadaran hemat energi dari masyarakat akan menjadi upaya nyata yang dapat dilakukan saat ini untuk menghadapi kelangkaan energi di masa yang akan datang. Selain itu, perlu upaya diversifikasi energi dalam kehidupan sehari-hari sehingga permintaan akan energi fosil khususnya dapat diturunkan serta dapat disimpan untuk masa yang akan datang.

\section{Kesimpulan}

Keberadaan energi saat ini telah menjadi sebuah komoditas strategis serta isu yang krusial bagi sebuah negara. Keadaan ini menciptakan kompetisi dalam rangka mendapatkan jaminan atas kelangsungan akses dan distribusi energi. Kompetisi ini menempatkan negara industri sebagai aktor utama dan negara berkembang dengan sumberdaya energi sebagai komoditas. Indonesia sebagai negara berkembang dengan cadangan sumber energi yang cukup besar perlu menyadari mengenai posisi serta dinamika dalam politik energi dari negara-negara besar. Indonesia perlu untuk melakukan penguatan posisi dalam politik energi melalui kebijakan energi dalam negeri yang bertujuan untuk meningkatkan bargaining position dalam rangka memenuhi kepentingan nasional dan bukan menjadi pelayan bagi kebutuhan energi negara industri semata. Namun kenyataan hingga saat ini kesadaran akan upaya untuk mengubah posisi Indonesia dalam 
politik energi global sangat sulit untuk diwujudkan. Apabila kondisi ini tidak segera ditangani melalui kebijakan yang tepat dalam tata kelola energi domestik bukan tidak mungkin Indonesia akan mendapatkan nasib yang sama dengan negara-negara lain yang telah terlebih dahulu merasakan bahwa cadangan energi mereka merupakan kutukan daripada sebuah anugerah.

\section{Daftar Pustaka}

Canton, J. (2009). Extreme Future. Ciputat: Pustaka Alvabet.

Chow, J., Kopp, R.J, \& Portney, P.R. (2003). Energy Resources and Global Development. Science 302(5650). pp. 1528-1531.

Deese, D. A. (1980). Energy: Economics, Politics and Security. International Security 4(3), pp. 140-153.

Elinur, et.al. (2010). Perkembangan Konsumsi dan Penyediaan Energi dalam Perekonomian Indonesia. Indonesia Journal of Agricultural Economics 2(1), pp. 98-119.

Gandhi, P. (2014). Analisis Kualitatif Nilai Ekspor Migas Indonesia dan Kepemilikian Blok Migas oleh Perusahaan Asing di Indonesia. Jurnal Ekonomi Pertanian, Sumber Daya dan Lingkungan 1, pp. 87-101.

Hunter, A. (1996). The Indonesian Oil Industry. Australian Economic Papers 5(5), pp. 59-106.

Hutagalung, et.al. (2015). Rencana Strategis 2015-2019 Kementerian Energi dan Sumber Daya Mineral. Jakarta: Kementerian ESDM.

Ja 'far, M. (2009) Energynomics. Jakarta: Gramedia Pustaka Utama.

Kementerian ESDM. (2010). Outlook Energi Indonesia. Jakarta: Kementerian ESDM.

Kementerian Negara Riset dan Teknologi. (2006). Buku Putih Energi: Indonesia 2005-2025. Jakarta: Kementrian Negara Riset dan Teknologi RI.

Mawikere, J.C. (2016). Implikasi Kuota Minyak Organization of Petroleum Exporting Countries (OPEC) dengan Kebijakan Keanggotaan dan Harga Bahan Bakar Minyak Pemerintah Indonesia Tahun 2008. Jurnal Analisis Hubungan Internasional 5(2), pp. 126-137.

Prasetyono, E. (2008). Energy Security: an Indonesia Perspective. Dalam: Marquina, A. eds, Energy Security Vision on Asia and Europe. New York: Palgrave Macmillan.

Rutledge, I. (2005) Addicted to Oil: America's Relentless Drive for Energy Security. London: IB Taurus.

Yani, Y.M, et.al. (2017). Pengantar Studi Keamanan. Malang: Intrans Publishing. 